Acta Crystallographica Section C

Crystal Structure

Communications

ISSN 0108-2701

\section{Bis $\left\{\left[\boldsymbol{\mu}-N, N^{\prime}\right.\right.$-bis(salicylidene)-1,4- butanediamine- $N, N^{\prime}, O, O^{\prime}$-copper(II)]- $\mu$-chloro-chloromercury(II) $\}^{1}$}

\author{
Ismail Ercan, ${ }^{\text {a }}$ Filiz Ercan, ${ }^{\text {b* Cengiz }}$ Arici $^{\mathbf{b}}$ and Orhan \\ Atakol $^{\mathrm{C}}$ \\ aAnkara Nuclear Research and Training Center, Beşevler 06100, Ankara, Turkey, \\ ${ }^{\mathbf{b}}$ Department of Engineering Physics, Hacettepe University, Beytepe 06532, Ankara, \\ Turkey, and ${ }^{\mathbf{c}}$ Department of Chemistry, Ankara University, Tandoğan 06100, \\ Ankara, Turkey \\ Correspondence e-mail: filiz@hacettepe.edu.tr
}

Received 27 September 2001

Accepted 15 November 2001

Online 31 January 2002

A new tetranuclear $\mathrm{Cu}^{\mathrm{II}}-\mathrm{Hg}^{\mathrm{II}}-\mathrm{Hg}^{\mathrm{II}}-\mathrm{Cu}^{\mathrm{II}}$ complex, $\left[\mathrm{Cu}_{2} \mathrm{Hg}_{2} \mathrm{Cl}_{4^{-}}\right.$ $\left(\mathrm{C}_{18} \mathrm{H}_{18} \mathrm{~N}_{2} \mathrm{O}_{2}\right)_{2}$ ], has been prepared by means of a copper complex found in the literature. The molecular structure of this complex was determined by X-ray diffraction and the $\mathrm{Cu}-\mathrm{Hg}-\mathrm{Hg}-\mathrm{Cu}$ chain was seen to be non-linear. The change in magnetic susceptibility with temperature was recorded for this complex and observed to abide by the Curie-Weiss law. The coordination around the $\mathrm{Hg}^{\mathrm{II}}$ ions is square pyramidal. The $\mathrm{Cu} \cdots \mathrm{Hg}$ bridging distance is 3.5269 (7) $\mathrm{A}$.

\section{Comment}

Organic-copper complexes have been used in pharmacology because the $\mathrm{Cu}^{\mathrm{II}}$ ion is an essential element for all living beings. Mercury is one of the most toxic elements for animals and humans because secretion of mercury from the human body is very difficult. For this reason, copper and mercury complexes are important in bioinorganic chemistry and a complex which contains both ions is very interesting. The most frequently observed coordination of the mercury(II)-organic ligand complexes in the literature is tetrahedral. If the complexes contain halogen ions, either dimerization or formation of planar rings in the structure $\mathrm{Hg} X \cdots \mathrm{Hg} X$ (the ring is defined as the $\mathrm{Hg}-\mathrm{Cl}-\mathrm{Hg}-\mathrm{Cl}$ ring) can be observed (Canty et al., 1979; Holy et al., 1976; Davidovic et al., 1998).

It has been known for some time that ONNO-type Schiff bases form polynuclear complexes with $\mathrm{Cu}^{\mathrm{II}}$ and $\mathrm{Ni}^{\mathrm{II}}$ complexes by reaction with many Lewis acids in non-aqueous solvents (Butcher \& Sinn, 1976; Aminabhavi et al., 1986; Yao et al., 1997; Atakol et al., 1999). A Cu-ONNO Schiff base complex previously prepared was reacted with $\mathrm{HgCl}_{2}$ in the

\footnotetext{
${ }^{1}$ Systematic name: di- $\mu$-chloro-2:3 $\kappa^{4} \mathrm{Cl}$-dichloro- $2 \kappa C l, 3 \kappa C l$-bis $\{\mu$-2,2' $-[1,4-$ butanediylbis(nitrilomethylidene)]diphenolato\}-1:2 $\kappa^{6} O, N, N^{\prime}, O^{\prime}: O, O^{\prime} ; 3,4 \kappa^{6} O$,$O^{\prime}: O, N, N^{\prime}, O^{\prime}$-dicopper(II)dimercury(II).
}

expectation that a $\mathrm{Cu}^{\mathrm{II}}-\mathrm{Hg}^{\mathrm{II}}$ heterometal complex would tend to dimerize, forming planar $\operatorname{Hg} X \cdots \mathrm{Hg} X$ coordination rings (Atakol et al., 1999). The molecular structure of the title compound, (I), was found to be tetranuclear through X-ray diffraction studies (Fig. 1). The complex structure was also studied using IR and element analysis techniques. In addition, the magnetic behaviour of the metal complex was measured in the temperature range $2-300 \mathrm{~K}$. The magnetic measurements indicate that the crystals are paramagnetic.

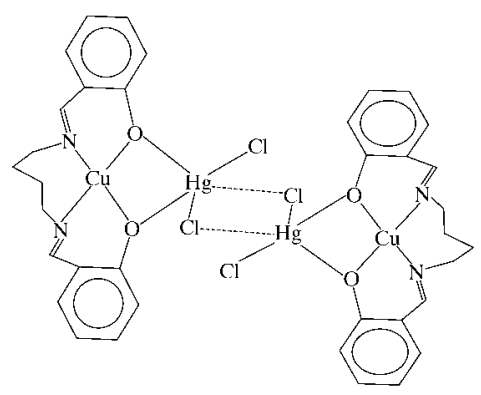

(I)

The seven-component chelate ring is not seen very often and most of the transition metal ions do not form this sevenmembered chelate ring. The seven-membered chelate ring composed of atoms $\mathrm{Cu}^{\mathrm{II}}, \mathrm{N} 1, \mathrm{C} 8, \mathrm{C} 9, \mathrm{C} 10, \mathrm{C} 11$ and $\mathrm{N} 2$ has a chair conformation. Similar to the six-component rings, the most stable form of the seven-membered ring is the chair. The $\mathrm{Cu}^{\mathrm{II}}$ ion has a distorted square-planar coordination involving two $\mathrm{O}$ and two $\mathrm{N}$ atoms from the salbd (salicylidene-butanediamine) ligand. The $\mathrm{Hg}^{\mathrm{II}}$ ion has a distorted squarepyramidal coordination. This coordination of the $\mathrm{Hg}^{\mathrm{II}}$ ion is unusual (Eliel \& Wilen, 1996).

In general, a $\tau$ value can be calculated from the angles around the central atom for a coordination number of five; $\tau=$ $(\alpha-\beta) / 60$ and $\alpha$ and $\beta$ are the largest two angles around the central atom. If $\tau=1$ then the coordination is an ideal trigonal bipyramid, whereas if $\tau=0$ then the coordination is an ideal

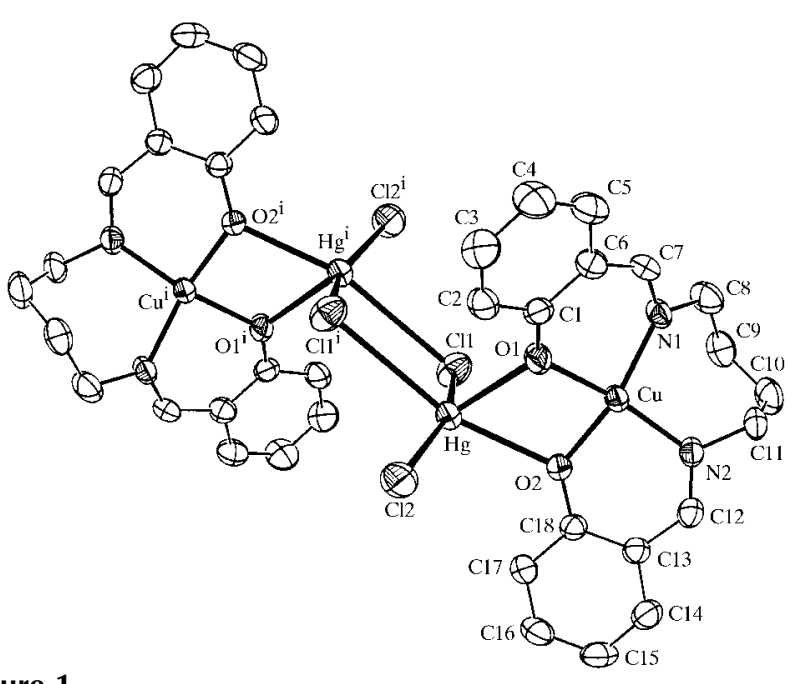

Figure 1

ORTEPII (Johnson, 1976) drawing of (I) with the atom-numbering scheme. Displacement ellipsoids are drawn at the $50 \%$ probability level. [Symmetry code: (i) $1-x, 1-y, 2-z$.] 
square pyramid (Addison et al., 1984). From the bond angles given in Table $1, \tau$ is 0.176 . As this value as close to zero, the coordination around $\mathrm{Hg}^{\mathrm{II}}$ is a square pyramid. The $\mathrm{Cu} \cdots \mathrm{Hg}$ and $\mathrm{Hg} \cdots \mathrm{Hg}(1-x,-1-y, 2-z)$ distances are $3.5269(7)$ and $4.3613(6) \AA$, respectively. The greatest $\mathrm{Hg} \cdots \mathrm{Cl}$ distance foundin the literature in an $\mathrm{Hg}-\mathrm{Cl}-\mathrm{Hg}-\mathrm{Cl}$ ring is $2.976 \AA$ (Davidovic et al., 1998). Although $\mathrm{Hg}^{\mathrm{II}}$ has been reported as generally having coordination numbers two and four, its coordination number in the tetranuclear complex can be taken as five.

\section{Experimental}

Salicyaldehyde, 1,4-butanediamine and the metal salts were obtained from Merck. The solvents were acquired from Carlo Erba and were used without further purification. The magnetic susceptibility of the powdered sample was measured between 2.6-300 K with a Faradaytype magnetometer at $1.2 \mathrm{~T}$. Experimental susceptibility data were corrected for the underlying diamagnetism. The magnetic measurements indicated that the heterometal tetranuclear complex was paramagnetic. The ligand was prepared by the condensation of salicyaldehyde and 1,4-butanediamine in EtOH (m.p. $603 \mathrm{~K}$, yield $94 \%)$. The complex was prepared in two steps. Step 1: $0.592 \mathrm{~g}$ $(0.002 \mathrm{~mol})$ of the ligand was dissolved in $50 \mathrm{ml} \mathrm{MeOH}$ with heating. A solution of $0.400 \mathrm{~g}\left[\mathrm{Cu}\left(\mathrm{CH}_{3} \mathrm{COO}\right)_{2}\right] \cdot \mathrm{H}_{2} \mathrm{O}$ in $50 \mathrm{ml}$ hot $\mathrm{MeOH}$ was added and the resulting solution mixed and left to stand for 3-4 h. The resulting precipitate was filtered off. $\mathrm{C}_{18} \mathrm{H}_{18} \mathrm{CuN}_{2} \mathrm{O}_{2}$, m.p. $>603 \mathrm{~K}$, yield $80 \%$. Step 2: $0.358 \mathrm{~g}$ of the complex prepared in Step 1 was dissolved at $363-373 \mathrm{~K}$ in a mixture of $20 \mathrm{ml}$ DMF (dimethylformamide) and $20 \mathrm{ml}$ dioxane. A solution of $0.272 \mathrm{~g} \mathrm{HgCl}_{2}$ $(0.001 \mathrm{~mol})$ in $30 \mathrm{ml}$ hot $\mathrm{MeOH}$ was added to this solution. The mixture was left to stand for 3-4 d. The precipitated crystals were filtered off and left to dry in the open. Elemental analysis, calculated for $\mathrm{C}_{36} \mathrm{H}_{36} \mathrm{Cl}_{4} \mathrm{Cu}_{2} \mathrm{Hg}_{2} \mathrm{~N}_{4} \mathrm{O}_{4}$ : C 34.33, $\mathrm{H}$ 2.86, N 4.45, Cl 11.27, $\mathrm{Cu}$ $10.10 \%$; found: $\mathrm{C} 34.46, \mathrm{H} 2.94, \mathrm{~N} 4.54, \mathrm{Cl} 11.23, \mathrm{Cu} 10.0 \%$. IR $\left(\mathrm{cm}^{-1}\right): v(\mathrm{C}-\mathrm{H})_{\text {arom }} 3029, v(\mathrm{C}-\mathrm{H})_{\text {aliph }} 2927, v(\mathrm{C}-\mathrm{H})_{\text {imin }} 2984$, $v(\mathrm{C}=\mathrm{N})_{\text {arom }} 1625, \delta(\mathrm{C}-\mathrm{H})_{\text {aliph }} 1472, \delta(\mathrm{C}-\mathrm{H})_{\text {arom }} 757, v(\mathrm{C}-\mathrm{O})_{\text {arom }}$ 1140 .

\section{Crystal data}

$\left[\mathrm{Cu}_{2} \mathrm{Hg}_{2} \mathrm{Cl}_{4}\left(\mathrm{C}_{18} \mathrm{H}_{18} \mathrm{~N}_{2} \mathrm{O}_{2}\right)_{2}\right]$
$M_{r}=1258.74$
Triclinic, $P \overline{1}$
$a=8.9927(12) \AA$
$b=9.4979(13) \AA$
$c=13.0245(14) \AA$
$\alpha=72.440(2)^{\circ}$
$\beta=69.285(3)^{\circ}$
$\gamma=73.023(3)^{\circ}$
$V=970.4(2) \AA^{3}$

$Z=1$

$D_{x}=2.154 \mathrm{Mg} \mathrm{m}^{-3}$

Mo $K \alpha$ radiation

Cell parameters from 25 reflections

$\theta=10.2-18.1^{\circ}$

$\mu=9.29 \mathrm{~mm}^{-1}$

$T=301(2) \mathrm{K}$

Prism, dark brown

$0.20 \times 0.15 \times 0.10 \mathrm{~mm}$

\section{Data collection}

CAD-4 EXPRESS diffractometer $\omega / 2 \theta$ scans

Absorption correction: empirical via $\psi$ scan (MolEN; Fair, 1990)

$T_{\min }=0.223, T_{\max }=0.395$

4114 measured reflections

3932 independent reflections

3482 reflections with $I>2 \sigma(I)$
Table 1

Selected geometric parameters $\left(\AA{ }^{\circ}\right)$.

\begin{tabular}{lclc}
\hline $\mathrm{Hg}-\mathrm{Cl} 1$ & $2.331(2)$ & $\mathrm{Cu}-\mathrm{O} 1$ & $1.933(6)$ \\
$\mathrm{Hg}-\mathrm{Cl} 1^{\mathrm{i}}$ & $3.300(2)$ & $\mathrm{Cu}-\mathrm{O} 2$ & $1.921(5)$ \\
$\mathrm{Hg}-\mathrm{Cl} 2$ & $2.321(2)$ & $\mathrm{Cu}-\mathrm{N} 1$ & $2.001(6)$ \\
$\mathrm{Hg}-\mathrm{O} 1$ & $2.420(5)$ & $\mathrm{Cu}-\mathrm{N} 2$ & $1.955(7)$ \\
$\mathrm{Hg}-\mathrm{O} 2$ & $2.562(5)$ & & \\
$\mathrm{O} 2-\mathrm{Cu}-\mathrm{O} 1$ & $83.6(2)$ & $\mathrm{Cl} 2-\mathrm{Hg}-\mathrm{O} 2$ & $100.32(15)$ \\
$\mathrm{N} 2-\mathrm{Cu}-\mathrm{N} 1$ & $98.1(3)$ & $\mathrm{Cl} 1-\mathrm{Hg}-\mathrm{O} 2$ & $96.17(15)$ \\
$\mathrm{Cl} 2-\mathrm{Hg}-\mathrm{Cl} 1$ & $153.80(12)$ & $\mathrm{Cl} 1^{\mathrm{i}}-\mathrm{Hg}-\mathrm{O} 2$ & $164.36(3)$ \\
$\mathrm{Cl} 2-\mathrm{Hg}-\mathrm{O} 1$ & $108.68(18)$ & $\mathrm{Cl} 1^{\mathrm{i}}-\mathrm{Hg}-\mathrm{Cl} 1$ & $79.96(3)$ \\
$\mathrm{Cl} 1-\mathrm{Hg}-\mathrm{O} 1$ & $96.99(18)$ & $\mathrm{Cl} 1^{\mathrm{i}}-\mathrm{Hg}-\mathrm{Cl} 2$ & $88.92(3)$ \\
$\mathrm{Cl} 1^{\mathrm{i}}-\mathrm{Hg}-\mathrm{O} 1$ & $103.40(3)$ & $\mathrm{O} 1-\mathrm{Hg}-\mathrm{O} 2$ & $62.04(18)$ \\
\hline
\end{tabular}

Symmetry code: (i) $1-x, 1-y, 2-z$.

\section{Refinement}

Refinement on $F^{2}$

$R(F)=0.057$

$w R\left(F^{2}\right)=0.149$

$S=1.09$

3932 reflections

236 parameters

$\mathrm{H}$-atom parameters constrained

$$
\begin{aligned}
& w=1 /\left[\sigma^{2}\left(F_{o}{ }^{2}\right)+(0.1197 P)^{2}\right. \\
& \quad+0.1203 P] \\
& \quad \text { where } P=\left(F_{o}{ }^{2}+2 F_{c}{ }^{2}\right) / 3 \\
& (\Delta / \sigma)_{\max }=0.003 \\
& \Delta \rho_{\max }=0.92 \mathrm{e} \AA^{-3} \\
& \Delta \rho_{\min }=-0.19 \mathrm{e}^{-3} \\
& \text { Extinction correction: SHELXL97 } \\
& \quad \text { (Sheldrick, 1997) } \\
& \text { Extinction coefficient: } 0.0026(8)
\end{aligned}
$$

$\mathrm{H}$ atoms were placed geometrically and refined using a riding model; $\mathrm{C}-\mathrm{H}=0.95$ or $0.99 \AA$ and $U_{\text {iso }}(\mathrm{H})=1.2 U_{\text {eq }}(\mathrm{C})$.

Data collection: CAD-4 EXPRESS (Enraf-Nonius, 1993); cell refinement: CAD-4 EXPRESS; program(s) used to solve structure: SHELXS97 (Sheldrick, 1997); program(s) used to refine structure: SHELXL97 (Sheldrick, 1997); molecular graphics: ORTEPII (Johnson, 1976).

The authors wish to acknowledge the purchase of the CAD-4 diffractometer under grant DPT/TBAG1 of the Scientific and Technical Research Council of Turkey.

Supplementary data for this paper are available from the IUCr electronic archives (Reference: BR1346). Services for accessing these data are described at the back of the journal.

\section{References}

Addison, A. W., Rao, J. N., Reedijk, J., Von Rijin, J. \& Verschoor, G. C. (1984). J. Chem Soc. Dalton Trans. pp. 1349-1356.

Aminabhavi, J. M., Biradar, N. S. \& Divakar, M. C. (1986). Indian. J. Chem. Sect. A, 25, 283-284.

Atakol, O., Arici, C., Tahir, M. N., Kenar, A. \& Ülkü, D. (1999). Acta Cryst. C55, 1416-1418.

Butcher, R. J. \& Sinn, E. (1976). Inorg. Chem. 15, 1604-1608.

Canty, A. J., Raston, C. L. \& White, A. H. (1979). Aust. J. Chem. 32, 1165-1166. Davidović, N., Matković-Čalogović, D., Popović, Z. \& Dragojević, I. V. (1998). Acta Cryst. C54, 574-576.

Eliel, E. L. \& Wilen, S. H. (1996). Stereochemistry of Organic Compounds, pp. 762-767. New York: John Wiley Interscience.

Enraf-Nonius (1993). CAD-4 EXPRESS. Version 1.1. Enraf-Nonius, Delft, The Netherlands.

Fair, C. K. (1990). MolEN. Enraf-Nonius, Delft, The Netherlands.

Holy, N. L., Baezinger, N. C., Flynn, R. M. \& Swenson, D. C. (1976). J. Am. Chem. Soc. 98, 7823-7824.

Johnson, C. K. (1976). ORTEPII. Report ORNL-5138. Oak Ridge National Laboratory, Tennessee, USA.

Sheldrick, G. M. (1997). SHELXL97 and SHELXS97. University of Göttingen, Germany.

Yao, H. H., Lo, J. M., Chen, B. H. \& Lu, J. H. (1997). Acta Cryst. C53, 10121013. 